\title{
Nature and Trend of GRI Reporting by Listed Firms in the NSE
}

\author{
Alhassan Haladu Dr. Basariah Bt. Salim \\ Tunku Puteri Intan Safinaz School of Accountancy (TISSA-UUM), \\ College of Business, Universiti Utara, Malaysia
}

\begin{abstract}
The major objective of the research is to examine how environmental information disclosure has been reported over the years through GRI disclosure standard and guidelines. The study considers environmentally sensitive firms listed in the NSE for the 6-year period ranging from 2009-2014. Data of the selected sample were analyzed using Excel13, SPSS22 and Stata13 to produce diagrammatic as well as statistical results. The outcome of evaluated data was very encouraging as it shows an average disclosure rate of $60.36 \%$ given by the simple average disclosure index. Besides, the discovery also pointed out that the rate of disclosure was higher after the adoption of the IFRS reporting system by the Nigerian government on $1^{\text {st }}$ January, 2012.It was therefore, recommended that environmental reporting be made mandatory and an effective and efficient enforcement of IFRS be done, so that positive trends in environmental reporting could be encouraged and maintained. The research covers a shorter period of just six years. This could be extended by further studies which may cover wider periods (10 years and above) and sectors (more than six) of the economy of a developing nation.
\end{abstract}

Keywords: -Environmental Nature, Environmental Trend, Environmental Reporting, Global Reporting Initiative $(G R I)$

\section{INTRODUCTION}

Environmental issues have become matters of grave concern in the world today. While much emphasis is on global warming due to climate change, flash floods, forest depletion, etc.; developing countries have their own unique environmental problems. In Nigeria Haggins and Frames (2011), pointed out that the major environmental concerns are desert encroachment, soil erosion, oil spillage and gas flaring. To this extent the federal government had established regulatory bodies in the form of the Department of Petroleum Resources (DPR) and National Environmental Standards and Regulations Enforcement Agency (NESREA) for the oil and non-oil and gas sectors respectively; to monitor and regulate environmental issues in the economy. Though not mandatory, firms under the new reporting system of the IFRS (International Financial Reporting System) are expected to make disclosure based on the Triple Bottom Line (TBL) system. This include companies making disclosure of information on profit, people and planet which denotes economic, social and environmental information disclosure.

Despite the threat on the environment, most developing nations are yet to see the need to make it mandatory like their counterparts in developed economies. Hence those that do, embark on voluntary disclosure. This does not compel individual and firms to disclose environmental information, nor are there any legislation on environmental disclosure. Though standards and rules exists together with membership of internationally recognize environmental associations, firms hardly comply with these standards and rules. Since 1985 several global environmental reporting organizations have been formed. They include Center for Corporate Citizenship (CCC) 1985, International Business Leaders Foundation (IBLF) 1990, Business for Social Responsibility (BSR) 1992, World Business Council for Sustainable Development (WBCSD) 1992, Social Accountability (SAI) 1997, Business Partners for Development (BPD) 1998, The Fair Labour Association (FLA) 1999, Business Action for Sustainable Development (BASD) 2000 and Global Compact (GC) 2000 (Othman \& Ameer, 2009). The availability of these sustainability reporting organizations gave rise to several reporting guidelines and standard among which are the Global Reporting Initiative (GRI), ISO14001, Greenhouse Gas Protocol (GGP), etc. to guide and regulate environmental disclosure (Asaolu, Agboola, Ayoola \& Salamu, 2011). These standards set out the manner in which environmental information should be disclosed.

Nigeria being a member of the international community has accepted the GRI which is the most dominant standard and guideline (Ballou, 2006; Creel, 2010). Firms are therefore, encourage to make disclosure following the principles of the GRI standard and guidelines. To know how environmental reporting has been behaving therefore, there is the need to examine disclosure over the years. The fact that there exists local standards and regulatory bodies on environmental issues necessitate the need for an investigation into how reporting on the issue has been made over the years. In this regard, the nature and trend of environmental

DOI: $10.9790 / 0837-2108100718 \quad$ www.iosrjournals.org $\quad 7 \mid$ Page


reporting forms the back bone and objective of this study. The nature entails the pattern of disclosing the basic components on the individual items or sub-items of the GRI disclosure standard and guidelines for companies. On the other hand the trend examines the behavior of these items of disclosure over a given period of time. Has it been rising or declining or mixed? These are the questions that this study attempts to provide answers to.

For simplicity purpose the write-up was divided into five parts. The first part is a brief background on the subject matter, tracing the problems of environmental reporting in Nigeria and stating the major objectives of the study. The second part is a review of environmental reporting concept, GRI and general literature on the issue. The third part states the methodology of the study and in part four, an evaluation of the disclosure nature and trend were made. The last part is a summary and conclusion of the entire research.

\subsection{The Concept of Environmental Reporting}

REVIEW OF RELEVANT LITERATURE

The concept of environmental reporting is a new information disclosure technique which enables firms to positively impact on environmental, social and communal forces. The suspicion by host communities that their livelihood is under threat from foreign forces like companies, may make these forces avoid drastic erosion, depletion and exploitation of whatever values the host considers threatened (Komblum \& Julian, 1980). For this reason Kasum (2010) believed that corporate social responsibility (CRS) is justified based on depletion of a community's resources by firms. Firoz and Ansari (2010), referred to environmental reporting as a discipline that concerns itself with the presentation of financial and nonfinancial information. This definition does not appear to be specific as the terms "financial and nonfinancial" are subject to interpretations. Though environmental reporting statements may appear similar, countries' unique social, local, economic and environmental differences could cause variations in them. In the light of this environmental reporting implies a commitment to environmental issues (Fortes, 2002). In environmental reporting emphasis is on reporting the impact of corporations operations on a range of stakeholders (Rahman, Hardin and Abubakar, 2010). It focusses on general issues like the policies of firms, environmental impacts, human rights, community development and sustainability.

Environmental reporting targets the need to know about what is being reported and the extent covered by the report on environmental issues. Pramanic, Shil and Das (2008) pointed out that environmental reporting also aimed at defining an organization's relationship with stakeholders in terms of information need. Wherever this information is not made available to concern parties the relationship appears threatened. Disclosure of certain information by firms is necessary because of the political sensitivity of some issues. A very good example is oil spillage in Nigeria that has attracted both local and international attention. Therefore, to attract foreign investors and avoid the powerful social and environmental lobbyist, environmental reporting is necessary. This may go a long way in boosting a firm's international image.

The benefits of environmental reporting are enormous. Nowadays environmental reports are criteria for selecting investments (Beets \& Souther, 1999). This is so because such statement are regarded as audited nonfinancial reports to show a firm's relationship with stakeholder. This clarify whether or not the business is a safe investment. These verified or audited reports could provide protection against litigation by either stakeholders or regulatory bodies on misrepresentation in environmental reports which, may help prevent issues of adverse penalties like bankruptcy or litigation (Beets \& Souther, 1999). Environmental reporting makes it possible for business to define their responsibilities and properly manage Environmental Impact Assessment (EIA). Such assessment must be consistent to enhance comparison in diversity and thus ease the distinction between environmentally sensitive and non-environmentally sensitive companies. Where environmental reporting is properly done the danger of "green glosses" publication is minimize. These are publications that emphasizes only on firms image. Environmental reports also determines the areas covered by environmental reporting. Environmental liabilities reported needs to be verified. Some liability costs reported don not address the need of host communities or other stakeholders. For instance where a company's operations end up damaging the soil of a farming community and the organizations responsible provides them with electricity and water supply as compensation, the expenditure does not in any way justifies the need of the community. Rather employment opportunity and embarking on land reclamation efforts may be appreciated. Environmental reports are therefore, necessary to determine proper and necessary environmental cost disclosures.

From the ethical perspective, environmental reporting lays the foundation for businesses code of conducts. Othman and Ameer (2009) and Malarvizhi and Yadav (2009), are of opinion that environmental reporting ethics helps greatly in evaluating cost-benefit effects and lays solid foundation for identifying and reporting environmental reporting information in order to support management's decision-making and control processes. In short, Pramanic et al. (2008), summarize the benefits of environmental reporting as to identify, mitigate and classify environmentally related operations expenditure. Furthermore, it takes measure to ameliorate the problems of conventional accounting practices in relation to environmental impact. It helps in resolving conflict between conventional accounting and environmental reporting. 
The concept of environmental reporting is faced by many challenges. Asaolu, Agboola, Ayoola and Salami (2011) posit that the biggest challenge of environmental reporting is the absence of a globally accepted environmental standard and guidelines and the limited qualified personnel in environmental reporting. Standards vary a lot according to Beets and Souther (1999) as could be seen from the different environmental organization listed earlier in the introduction of this research. The few professionals available also charge exorbitant fees for their services. The fear of legal actions which may be brought about by negative and adverse public opinion on firm's environmental report is also a problem of environmental reporting. Environmental problems that were previously unknown may be brought to light by an environmental report. This may spark fresh outcry.

\subsection{The GRI Environmental Disclosure Standards}

With the coming of environmental reporting several reporting regulations, guidelines and standards were established. Among the prominent ones are GRI, ISO14001, Greenhouse Gas Protocol (GGP), AA1000 and Social Accounting 8000 (SA8000). However voluntary guidelines and standards issued by the GRI and ISO14001 have been acclaimed the most popularly accepted (Ballou, 2006; Brown, de Jong, \& Lessidrenska, 2007). According to Ballou (2006), Brown, de Jong, \& Lessidrenska (2007) and Othman and Ameer (2009), the GRI is a brainchild of the UNDP (United Nations Development Program). The GRI is a network based nongovernmental organization with the objective of fostering sustainability reporting by developing guidelines and standards for environmental information disclosure (GRI, 2011). The standard is used by business organizations to measure and report economic, social and governance performance (International Trade Centre, 2015). It is very comprehensive and have international acclamation. The first guidelines of the GRI were published in 2000 (G1) which, focusses primarily on the contents of an environmental reports. The upgraded version of G2 (2002) recommends a structure for reports on sustainability issues with six key elements. The most important characteristics of GRI is that it has no limit in length and emphasizes full application of framework guidelines. GRI's major aim is enhancing quality, rigor and utility of sustainability reporting (Ballou, 2006). The standard tries to formulate guidelines that are universal. As the standard works very closely with the United Nations, it has the fastest growing rate of corporate body's membership to the extent that by 2006 nearly 1000 corporate firms from almost 60 countries have registered with and are using it (Ballou, 2006; Creel, 2010).

The GRI framework is based on nine (9) fundamental principles. The first is the "materiality" principle which seeks to capture topics and indicators that are of economic, social and environmental nature and significant enough to influence the desires of stakeholders. The second principle is the "stakeholder inclusiveness" principle which recognizes that stakeholders be identified and consulted on their interest. A corollary to this principle is the "sustainability context" principle. This principle examines the past, present and future of sustainability items by noting what was there, what is being exploited and how does the firm intends to improve the deteriorated environment or society. The "complete" principle demands that the environmental report must be full showing social, economic and environmental impact. The $5^{\text {th }}$ principle is the "balance" principle. It states that a GRI report must be fair, objective and well balance to reflect good, bad, positive and negative aspects of an organization's operational performance. An environmental reports must be comparable to other reports of different time periods, firms, industries, sectors or economies as propounded by the "comparable" principle. Reported information in GRI reports should make it possible for users to be able to performance analyses for different organizations and period. The other principle is the "accuracy" principle. This principle emphasizes that qualitative and quantitative measurements should be detailed and accurate enough for interested parties to comprehend the organization's performance. The "timely" principle requires a GRI report to be produced in time in order for users to effectively integrate it into their decision making process. Reports also need clarity of expressions, this is what the "clarity" principle stands for. For proper comprehension, understanding and accessibility, the method of dissemination used must be simplified enough for easy digestion; be it pictorial, graphical, diagrammatic or numeric. The final principle is the "reliability" principle. To ensure reliability of GRI reports, data used as well as processing methods should be valid and qualitative. The process of gathering, compiling, analyzing and disclosing information should be qualitative, material and subject to examination.

As earlier stated several upgrade has been made on GRI since the $1^{\text {st }}$ version of G1. There has been G2, G3.0, G3.1 and G4 versions. Major components of G4 version include (GRI, 2013):
a. Strategy and analysis
b. Organizational profile
c. Identified material aspects and bodies
d. Stakeholders engagement
e. Report profile
f. Governance
g. Ethics and integrity 
h. Management approach and indicators

Strategy and analysis contains a statement from the Chief Executive Officer (CEO) on the relevance of sustainability to the business and what strategy does the organization have on sustainable development. In addition to this the management must outline key social and environmental impacts, risks, and opportunities. (GRI 1.1-1.2).

Organizational Profile contains the name of the organization, primary brand, products, or services, operational structure, principal office of residence, number of countries of operation, nature of ownership and legal form, markets, number of employees, net sales, capital structure, total assets, significant changes during the period and awards received during the reporting period. (GRI 2.1-2.10).

Report Parameters encompasses accounting year-end, recent report, reporting cycles, boundary of reports, boundary of report limitations, basis for reporting, data measurement techniques, explanation of re-statement, significant changes and content index to identify the location of standard disclosures. The organization's policy on Auditing and Assurance should also be disclosed. (GRI 3.1-3.13).

Governance, Commitments and Engagements aspect of the organization should show the organizational structure, duality, number of Board members, recommendation mechanism, conflict of interest resolution process, qualifications and expertize of Board members, mission statement, TBL management strategy and the performance appraisal on management. The organization must also reveal its commitments to external initiative. There must be an explanation on how management intends to address risk management in operational planning or the introduction of new product, development of economic, environmental, social agreement, and industrial membership or Association. Disclosure on stakeholder management should show list of stakeholders (individuals or groups), basis of identifying stakeholders, stakeholder's engagement approach, and key issues raised by stakeholders. (GRI 4.1-4.17).

Management approach and performance indicators should be disclosed in relation to economic performance, market presence and indirect economic impact, organizational objective and organizational policy. For simplicity purposes the section is categorized into economic, environmental, and social categories.

a. The economic dimension of sustainability centres on two basic items: the flow of capital among stakeholders and the economic impact of the organization throughout society. Economic performance covers revenue, financial implications of risks and opportunity of the organization, benefit plan obligations and financial assistant from government. Market presence should disclose organization's policy on branches, market ratios, and local employment procedures. The indirect economic impact consists of infrastructure and services provided for public benefit and describing significant indirect economic impact.

b. The environmental dimension concerns an organization's impact on the economic system. This disclosure covers performance related to inputs and outputs such as material, energy, water, emissions, effluents, biodiversity, and wastes. Also disclosure should be made on departments in charge of environmental aspects, training and awareness, monitoring and follow-up, environmental success and shortcomings, risks and opportunities, major changes to the environment and key environmental strategies.

c. On the social performance there should be disclosure of the goals and performance, social policy, organizational responsibility, training and awareness, monitoring and follow-ups on social issues, employment, management's relationship with the community, health and safety, training and education, diversity and equal opportunities on the following: labour practice and decent work, human rights, society (community), and product responsibility.

d. There should be a general reporting note on data gathering, report form and frequency and assurance.

Moreover the G4 reporting recommends specification of the following (GRI, 2013):

1. Identified material aspects and boundaries disclosures should include the following:

a. A list of all the organizations subsidiaries or sub-subsidiaries (if any).

b. The process for defining Report Content and Aspect Boundaries.

c. A list of all Material Aspects (economic, environmental, and social).

d. A statement on whether Material Aspects are within or outside the organization.

e. State the effects of restatement of information.

f. Report on significant changes in Scope and Aspect Boundaries.

2. Stakeholder engagements should disclose:

a. A list of Stakeholders and their basis of selection.

b. The organization's approach to Stakeholder Engagement.

c. Key concerns raised with stakeholder and the organization's response to them.

3. Report Profile contains important information on GRI Content Index and method of soliciting external Assurance. It discloses:

a. Date of most recent Report.

b. Reporting periods (weekly, monthly, quarterly, biannually, or annually).

c. The provision of contact Point for questions on Report Contents. 
d. Show the "in accordance option", GRI Content Index, and reference to External Assurance Report.

4. Governance Structure and Composition disclosure is necessary for transparency and accountability (GRI, 2013). It contains:

a. Organizational governing structure especially on economic, environmental, and social impacts.

b. Process of delegation of authority with regards to economic, environmental, and social topics.

c. The availability of executive members on economic, environmental, and social responsibilities.

$\mathrm{d}$. The process of consultation between management and stakeholders.

e. Board characters like non-executive members, independence, numbers, tenure, gender, social group's representatives, technocrats, and stakeholder representatives.

f. Dual membership.

g. Method of Board appointments.

h. Management of conflict of interest.

i. Board's role in setting purpose, values, and strategy.

j. Boards competency and performance evaluation.

$\mathrm{k}$. Board's role in risk management.

1. Board's role towards sustainability reporting.

m. Remuneration and incentive policies.

5. Ethics and Integrity disclosures must contain organization's values, principles, standards, norms, advice on ethical and legal behaviours, and reporting unethical, unlawful, and matters of integrity.

2.3 Global Reporting Initiative (GRI) Empirical Results

Brownet al., (2007) traced the development of GRI since inception in 1999. They noted that the standard has gradually worked its way to the top of voluntary sustainability reporting system. GRI was able to attain this feat due to its provision of multi-stakeholder process, institutionalization of the reporting process and establishing an institution to serve as the custodian of the guidelines and process. Despite limited resources, visibility, and political power, GRI have been able to achieve a win-win solution for all actors (Brown et al., 2007). However, balancing competing objectives like between individual and collective interests, by GRI has left a legacy of unresolved tension from its trade-offs. This inconclusiveness and multi-stakeholder participation may serve as fuel for effecting social change.

Shedding light on the dynamics and the potential of transparency policies was the contribution of Dingwerth and Eichinger (2010) to their study of GRI. Investigating the tension of how transparency policies empowered users of disclosed information as against reporters seeks to know the relevance of data on sustainability if the aim is to empower users rather than producers (Dingwerth \& Eichinger, 2010). The result of their work showed that GRI has had little impact in shifting the balance of power in corporate governance towards society. Those whose interests are threatened by the shift of power will seriously oppose transparency policies. While empowerment may be used to justify transparency policies, the policy can survive even without empowering users.

Hedberg and von Malmborg (2003) tackled the question on the emphasis of GRI by modern firms. From the survey of all Swedish companies that uses GRI guidelines, they discovered that companies produced reports mainly to seek legitimacy, increased credibility, and internal communication. Thus, visibility and control of TBL was effective by GRI guidelines. Jenkins and Yakovleva (2006) explored trends in reporting of environmental impacts and issues in mining industries. Using a case study of the largest 10 global mining companies their analysis showed evidence of increasing sophistication on GRI disclosure development, variation in the maturity of reporting context and style of these companies. These companies were classified into "leaders" and "laggards" (Jenkins \& Yakovleva, 2006). Thus, strong leadership and cooperation from leaders is a necessary support for laggards in the industry.

GRI's success can be attributed to "institutional entrepreneurs" (Levy, Brown, \& de Jong, 2010). The standard has failed to use disclosure to make users of disclosed information more powerful than presenters of such information (for example non-governmental organizations). Alonso-Almeida, Llach and Marimon (2012) evaluates the diffusion of GRI in all sectors of the economy. Their application of logistic curve model and the instability and concentration indices were used to assess the diffusion process. Paying more attention to the financial and energy sectors, results suggests that firms due to their visibility, pollution, and internationality adopted GRI. The use of GRI could enable firms gain market, credibility, attract new investors, and identify new legitimate identities (Alonso-Almeida et al., 2012).

TBL has become institutionalized through the GRI reporting guidelines (Milne, Ball \& Gray, 2005). They reported the narrow and incomplete reporting practices by organizations' that later make stronger claims for sustainability. They argue about the insufficiency of TBL and GRI for organizations' contribution to the earth's economy. Evidence from practices seems to show that GRI does not increase on accountability by reporting on environmental, economic, and social performance of organizations (Moneva, Archel \& Correa, 
2006). Some organizations' irresponsible behaviours with regard to gas emission, social equity, and human rights continue. This faults the sustainability development approach adopted by the GRI guidelines.

Sherman (2009) explored the value added of GRI (G3) to external reporting of company's economic, environmental and social performance. He concluded that if the aim of G3 is to compare and contrast companies like Nike and Adidas, then the guidelines of G3 have failed and there is a long way to go in establishing a new guidelines. The Japanese approach to CSR may be well differ from the Western approach due to differences in socio-economic characteristics. After conducting empirical tests Tanimoto and Suzuki (2005), discovered that the adoption of GRI guidelines by Japanese firms marks the erosion of traditional corporate-centered system of Japan. Moreover, the way of adoption differs significantly between Japan and the West, which may be a sign of cultural resistance to total convergence. Heightened interest in nonfinancial reporting can only enhance demand for more wide spread sustainability reporting (Woods, 2003). Assurance guidelines was crucial because the accounting profession is opportune to play a significant role in this regard. They should therefore, familiarize themselves with GRI and its work (Woods, 2003).

In summary, research on GRI has spread widely from studies that looked at balancing competing objectives to the use of GRI in empowering users of it and various conclusions have been drawn. The question of why emphasize on the GRI as the most popular nonfinancial reporting tool in almost all sectors especially the mining sectors, has also been covered widely. Some studies sees GRI as having failed in producing adequate economic, environmental and social information for sustainability development thereby questioning its accountability and value-added. In Nigeria, there are specialized government agencies and institutions charged with the responsibility of ensuring compliance with environmental guidelines and standards. Attempt has been made in this study to relate the latest version of GRI (G4) to environmental information disclosure in environmentally sensitive sectors of the Nigerian economy as a developing country.

\section{III.}

\section{METHODOLOGY}

The study's major aim is an evaluation of the nature and trend of environmental disclosure by environmentally sensitive firms listed in the NSE. To effectively perform this function the design involves defining the population, selection of appropriate sample size and sources, and the use of proper analytical tools. The population of the study in general terms constituted all firms listed in the NSEthat are environmentally sensitive. The criteria for environmental sensitivity is the ability for a firm to negatively impact the environment where it performs its operational activities. These include firms that are primarily engaged in activities like agriculture, construction, manufacturing, mining, etc. Of the thirteen (13) sectors of firms quoted in the NSE six (6) sectors fell into this category namely: agriculture, construction/real estate, healthcare, industrial goods, natural resources and oil\& gas. The operations of firms in these industries caused devastation to the environment. From air pollution to land pollution to water pollution, their activities impact directly or indirectly on the environment. The total number of firms listed in this sector are 81 (NSE Factbook 2012/2013).

Using Collins \& Schultz formula as applied by Kantudu (2006), Nyor (2008), and Enahoro (2009); a sample of 67 firms was chosen at random pro-rata based on industrial type as the sample for this research. These 67 firms evaluated for the 6-year period spanning from 2009 to 2014, gave a total of 402 observations. Secondary sources forms the major source of data (annual financial statements). The procedure used 33 items of disclosure from the GRI disclosure standard and guidelines classified into 10 groups based on the nature of the sustainability. The ten groups of items and their codes are strategy \& analysis (SD1), organizational profile (SD2), governance (SD3), economic issues (SD4), environmental issues (SD5), social issues (SD6), labour practices \& decent work (SD7), human right issues (SD8), product responsibility (SD9) and ethical policies on environment (SD10). Each item of the 33 items disclosed attracts 1 score, while non-disclosure attracts 0 score. SD1, SD2, SD3 and SD5 have maximum scores of 5 marks; SD6 and SD7 have maximum score of 4 marks, SD4 3 marks maximum, SD8 2 marks maximum and SD9 \& SD10 have maximum of 1 mark each. These scores represent the weight of items in each group.

This content analysis method proved valid and reliable as both validity and reliability tests produced scores of 0.883 (KMO) and 0.917 (Alpha) respectively, both of which are within the acceptable validity and reliability score range. For each observed disclosure a simple average disclosure index (SADI) was computed by taking the simple average of each observation. The SADI which, has a scale of 0 to 1 showing lowest and highest levels of disclosure respectively, was the major determinant of the level and magnitude of disclosure by a firm expressed in percentage. A comparison was made between the period before the adoption of IFRS (20092011) and the period after its adoption (2012-2014). The tools of analysis used for the study include SPSS22, Excel13 and Stata13. While SPSS22 was used for the computation of reliability, validity and JonckheereTerpstra (J-T) tests; Stata13 and Excel13 were applied in estimating the descriptive statistics and graphical/diagrammatical presentation of results from analysis through diagrams and figures. Interpretation was then done through content analysis to arrive at the findings of the study. 
IV.

DATA PRESENTATION AND ANALYSIS

4.1 Introduction

The analysis of the study constitutes three major parts. The descriptive statistics which spells out the average disclosure, standard deviation and the number of observations made for the period covered (2009-2014). The next stage of analysis looks at the pattern of disclosure depicting the level of disclosure. The final stage examines the trend of disclosure over the period covered. Emphasis was laid on the behavior of the trend to determine whether it is smooth and continuous or fluctuating.

4.2 Descriptive Statistics

Table I Average Environmental Disclosure

\begin{tabular}{l|ccc|cr} 
Variable & Mean & Std. Dev. & \multicolumn{2}{c}{ Observations } \\
\hdashline Strt. \& anal & 3.027363 & 1.607882 & $\mathrm{~N}=$ & 402 \\
Org. profile & 3.211443 & 1.611235 & $\mathrm{~N}=$ & 402 \\
Governance & 3.589552 & 1.655698 & $\mathrm{~N}=$ & 402 \\
Eco. Issues & 2.99005 & .1219153 & $\mathrm{~N}=$ & 402 \\
Env. Issues & 2.300995 & 1.600015 & $\mathrm{~N}=$ & 402 \\
Soc. Issues & 1.932836 & 1.312881 & $\mathrm{~N}=$ & 402 \\
Labour prac. & 1.047264 & .7408662 & $\mathrm{~N}=$ & 402 \\
Hum. Rigt. Issue & 1.014925 & .7235105 & $\mathrm{~N}=$ & 402 \\
Product Resp. & .3134328 & .4644667 & $\mathrm{~N}=$ & 402 \\
Ethical policies & .3606965 & .480801 & $\mathbf{N}=$ & 402 \\
SADI & .603606 & .2564115 & $\mathbf{N}=$ & 402
\end{tabular}

Source: Stata13

Table 1 and Figure 1 are indications of the mean disclosures. The disclosure for SD1, SD2, SD3 SD4, SD7 and SD8 were above average while that of SD5, SD6, SD9 and SD10 are below average. The standard deviations of the distribution showed acceptable variations from the mean even though SD1, SD2, SD3, SD5 and SD6 are a little bit uneven because of the magnitude of the standard deviation. The overall distribution could however, be acceptable. Of much significant is the mean value of the SADI. It shows an average disclosure of $60.36 \%$ by firms in sensitive sectors of the Nigerian economy. With a standard deviation of 0.2564 , it means the variation in the distribution was even. The percentage disclosure is an indication of the high priority given by firms in the sector to environmental issue. Given the fact that environmental disclosure is voluntary the value of disclosure marks a significant step forward.

Figure 1. Average Disclosure of GRI Items

\section{AVERAGE PATTERN OF ENVIRONMENTAL DISCLOSURE (2009-2014)}

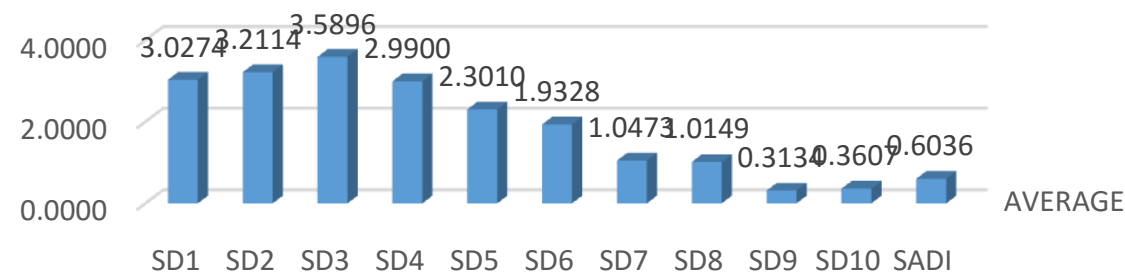

Source: Excel13

4.3 Nature of Disclosure

Figure 2 is an indication of the pattern of disclosure for all ten items plus the average disclosure index (SADI) for the period observed. Except for SD4 all other items showed fluctuating pattern of disclosed over the period spanning 2009-2014. The rising and falling over the years showed that disclosed started at lower level in 2009 rose, then falls slightly in 2011 before picking up again in 2012 to maintain a slight increase up to 2014. Figure 4 gives a clear indication of this behavior over the period by each of the disclosed items. While all items shows 
elements of fluctuation in an undulating manner, only SD4 maintains a straight line shape. Figure 5 shows the industrial/sectoral pattern of distribution.

\section{Figure 2. Annual Disclosure of GRI Items}

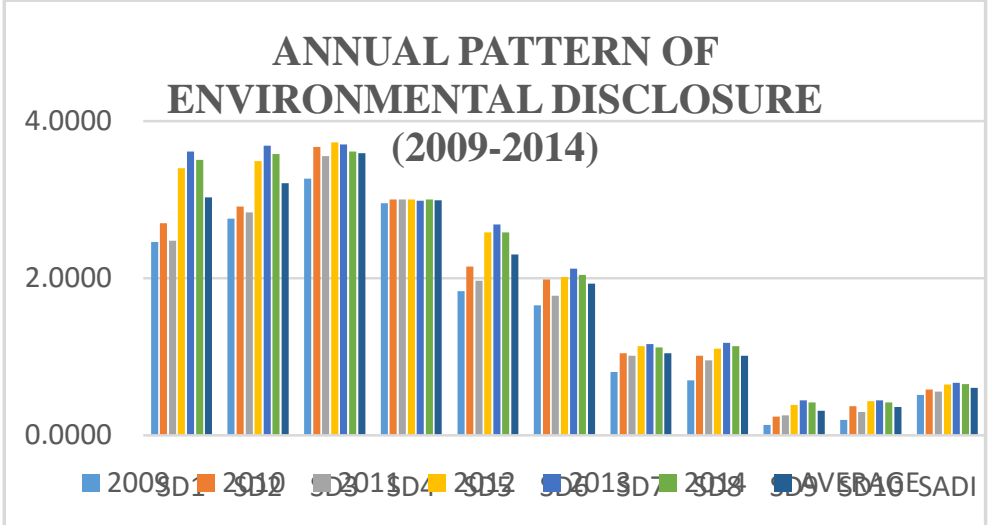

Source: Excel13

Table 2 Pre (2009-2011) and Post-IFRS (2012-2014) Environmental Disclosure

\begin{tabular}{|l|l|l|l|}
\hline \multicolumn{1}{|c|}{ VARIABLE } & Pre \& Post IFRS & N & Mean \\
\hline Strategy \& Analysis & 1 & 201 & 2.5500 \\
& 2 & 201 & 3.5100 \\
\hline Organizational Profile & 1 & 201 & 2.8400 \\
& 2 & 201 & 3.5900 \\
\hline Governance, Commitment \& & 1 & 201 & 3.5000 \\
Engagements & 2 & 201 & 3.6800 \\
\hline Economic Issues & 1 & 201 & 2.9900 \\
& 2 & 201 & 3.0000 \\
\hline Environmental Issues & 1 & 201 & 1.9900 \\
& 2 & 201 & 2.6200 \\
\hline Social Issues & 1 & 201 & 1.8100 \\
& 2 & 201 & 2.0600 \\
\hline Labour Practices \& Decent Work & 1 & 201 & 0.9600 \\
& 2 & 201 & 1.1400 \\
\hline Human Rights Issues & 1 & 201 & 0.8900 \\
& 2 & 201 & 1.1400 \\
\hline Product Responsibilities & 1 & 201 & 0.2100 \\
& 2 & 201 & 0.4200 \\
\hline Ethical Policies on Environmental & 1 & 201 & 0.2900 \\
& 2 & 201 & 0.4300 \\
\hline Environmental Information & 1 & 201 & 0.5509 \\
Disclosure & 2 & 201 & 0.6564 \\
\hline
\end{tabular}

Source: SPSS22 
Figure 3

Industrial/Sectoral Disclosure of GRI Items

\section{SECTORIAL PATTERN OF ENVIRONMENTAL REPORTING (2009-2014)}

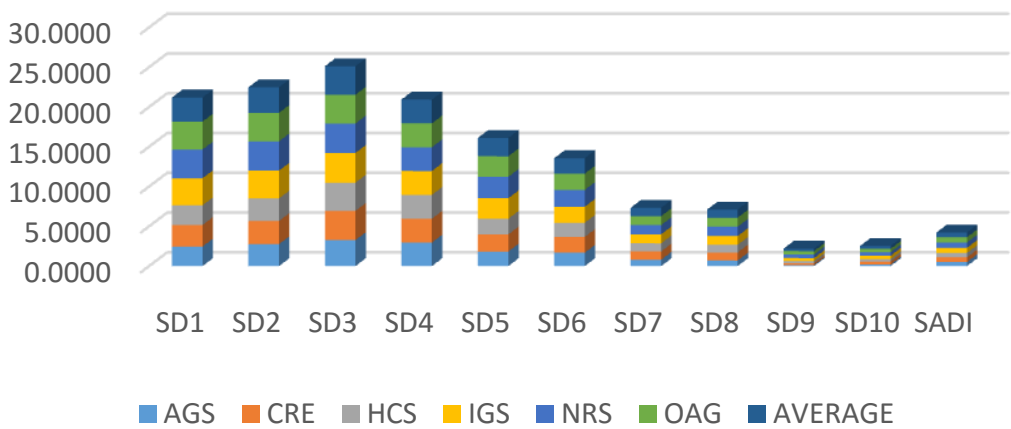

Source: Excel13

\subsection{Trend of Disclosure}

The level of disclosure showed that average disclosure was higher after IFRS (International Financial Reporting Standards) adoption. Table 2 showed that the mean disclosure for post-IFRS (2) is higher when compared to pre-IFRS (1) for all the items with the SADI result reading as $55.09 \%$ and $65.64 \%$ for pre and post-IFRS periods respectively. This shows a significant rise in the trend of disclosure of over 10\%. Table 3 further describe this trend using J-T test. All the variables with the exception of SD4 which denotes economic issues, showed significant levels of increase. The implication is that the average level of disclosure increased at a significant rate over the periods observed. A look at the average disclosure (SADI) showed highly significant level of increase at $1 \%$ level of significance.

Table 3 Jonckheere-Terpstra Test (J-T test)

\begin{tabular}{|l|c|c|}
\hline \multicolumn{1}{|c|}{ VARIABLES } & $\begin{array}{c}\text { STANDAR } \\
\text { D J-T } \\
\text { STATISTIC } \\
\end{array}$ & $\begin{array}{c}\text { SIGNIFICA } \\
\text { NCE }\end{array}$ \\
\hline Strategy \& Analysis & $\mathbf{5 . 6 7 4 0}$ & $\mathbf{0 . 0 0 0 0}$ \\
\hline Organizational Profile & $\mathbf{4 . 7 7 1 0}$ & $\mathbf{0 . 0 0 0 0}$ \\
\hline Governance & $\mathbf{1 . 9 0 0 0}$ & $\mathbf{0 . 0 5 7 0}$ \\
\hline Economic Issues & $\mathbf{1 . 1 8 9 0}$ & $\mathbf{0 . 2 3 5 0}$ \\
\hline Environmental Issues & $\mathbf{3 . 7 9 1 0}$ & $\mathbf{0 . 0 0 0 0}$ \\
\hline Social Issues & $\mathbf{1 . 6 8 9 0}$ & $\mathbf{0 . 0 9 1 0}$ \\
\hline Labour Practice \& Decent Work & $\mathbf{2 . 7 1 8 0}$ & $\mathbf{0 . 0 0 7 0}$ \\
\hline Human Rights Issues & $\mathbf{3 . 7 4 8 0}$ & $\mathbf{0 . 0 0 0 0}$ \\
\hline Product Responsible & $\mathbf{4 . 5 9 0 0}$ & $\mathbf{0 . 0 0 0 0}$ \\
\hline Ethical Environmental Policies & $\mathbf{3 . 0 0 7 0}$ & $\mathbf{0 . 0 0 3 0}$ \\
\hline Simple Average Disclosure Index & $\mathbf{4 . 2 1 5 0}$ & $\mathbf{0 . 0 0 0 0}$ \\
\hline
\end{tabular}

Source: SPSS22 
Figure 4

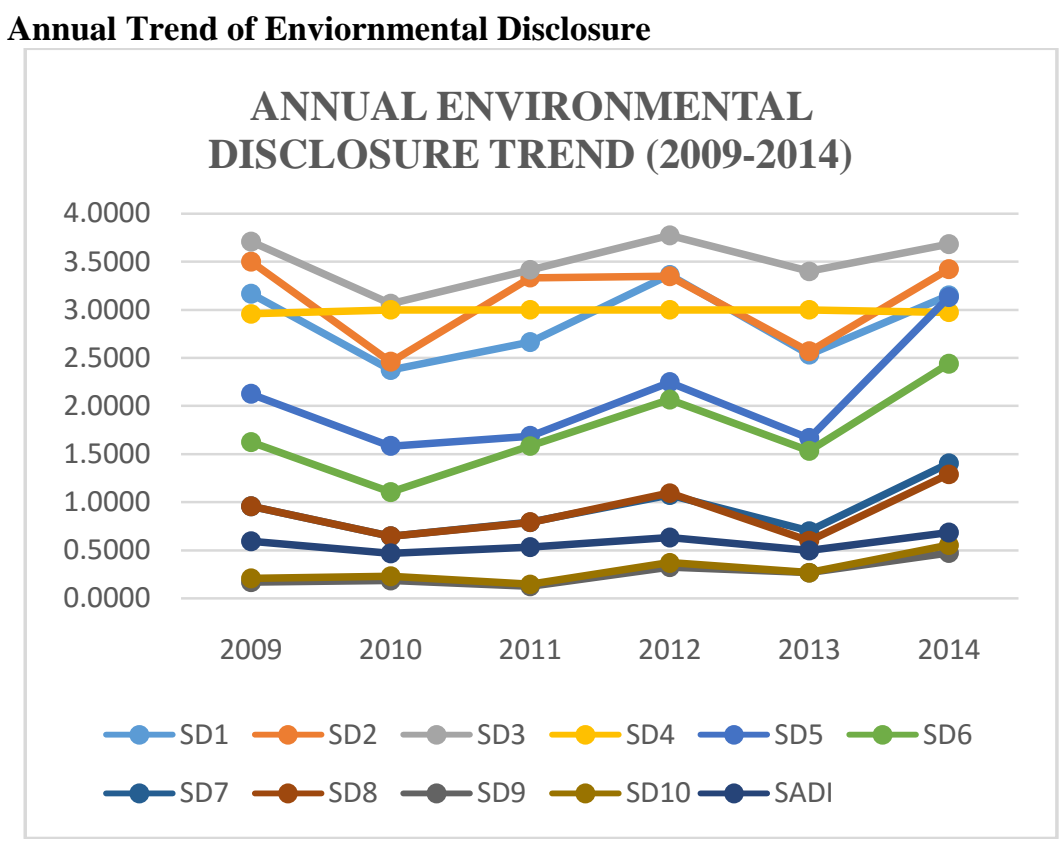

Source: Excel13

\section{CONCLUSION AND RECOMMENDATIONS}

$5.1 \quad$ Summary

The suspicion by affected local communities of threats over their livelihood from foreign forces may necessitate environmental reporting. Nigeria's major environmental concerns today are desert encroachment, soil erosion, oil spillage and gas flaring. The role of DPR and NESREA in combating these cannot be over emphasized. The study examines the nature and trend of environmental reporting by environmentally sensitive firms listed in the NSE. The nature of disclosure comprises the disclosure pattern of the individual components of GRI standard and guidelines. Environmental reporting as a discipline is concern with the presentation of financial and nonfinancial information of firms. The most accepted environmental disclosure standard currently is the GRI (G4) which, has comprehensive requirement based on TBL. Studies showed that though GRI has worked its way to the peak of voluntary sustainability reporting system, most developing nations are yet to fully implement it (Brown et al., 2007). However, by trying to attain a balanced objective GRI is leaving behind a legacy of unresolved tension. The study covers mainly sensitive firms listed in the NSE for a six-year period. The key element analyzed was the disclosure index (SADI) using content analysis, SPSS22, Excel13 and Stata13. It was discovered that $60.36 \%$ of items were disclosed by firms in the sector/industry.

\subsection{Findings and Conclusions}

From the analysis of the data of this research the following were discovered:

1. There was a very high and significant level of environmental disclosure by firms in the environmentally sensitive sector of the Nigerian economy listed in the NSE, this notwithstanding the fact that social and environmental reporting in Nigeria is voluntary. The disclosure level of $60.36 \%$ by the sector is significantly high for a sector operating in a developing economy where there are no legislation on mandatory environmental reporting.

2. The nature of disclosure is such that on average $63.64 \%$ of the items disclosed including the SADI, were above average level of disclosure. Only SD5, SD6, SD7 and SD10 had items disclosed below 50\% of their level of disclosure. In general while the majority of disclosed items have higher disclosures the remaining $36.36 \%$ have lower levels of disclosure.

3. The disclosure trend was mixed with disclosures rising and falling over the periods observed. Specifically the pre-IFRS period saw lower levels of disclosures compared to the post-IFRS period. There was a significant rise of about $10.55 \%$ between the two periods. However, the trend kept on fluctuating throughout the period. From a lower level in 2009 it rose for some time, fell and pick up again to end up rising in 2014. 
4. Variations in data spread was even with about $54.55 \%$ of data used for the study evenly distributed. Variation in distribution of majority of our observation was normal and this helps in strengthened the prediction of this study.

5. Disclosure after the adoption of IFRS was significantly high to the tune of $65.64 \%$.

\section{$5.3 \quad$ Recommendations}

The following recommendations were made based on the above discoveries.

a. The authorities should encourage firms in the industry and the sector by offering incentives such as tax cuts, to improve on the current level of environmental reporting by firms that are environmentally sensitive.

b. Environmental reporting must be made mandatory to at least maintain the current high level of disclosure. This could be achieved by the enactment of legislation that makes environmental information disclosure through recognized environmental disclosure standards and guidelines like GRI, legal and compulsory.

c. The problems of fluctuations in the nature and trend should be investigated and necessary measures taken to avoid it so that the pattern and level of disclosure will be smooth, continuous and positive.

d. Since Nigeria has now adopted the IFRS reporting standard, its enforcement should be strengthened in an effective and efficient manner in order to encourage and maintain the positive trend in environmental information disclosure.

\section{REFERENCES}

[1] Alonso-Almeida, M., Llach, J., \& Marimon, F. (2012, November $23^{\text {rd }}$ ). A closer look at "global reporting initiative" sustainability reporting as a tool to implement environmental and social policies: A worldwide sector analysis, 21; 318-335.

[2] Asaolu, T. O., Agboola, A. A., Ayoola, T. J., \& Salamu, M. K. (2011). Sustainability in the Nigerian oil and gas sector. Environmental Management Conference Proceedings, Federal University of Agriculture Abeokuta, Nigeria.

[3] Ballou, B., Heitger, D. L. \& Landes, C. E. (December 2006). The future of corporate sustainability reporting - a rapid growing assurance opportunity. Journal of Accountancy. http://www.starbucks.com

[4] Beets, S. D. \& Souther, C. C. June 1999). Corporate environmental reports: the need for standards and an environmental assurance service. American Accounting Association's Accounting Horizons. 13(2); 129-145.

[5] Brown, H. S., de Jong, M., \& Lessidrenska, T. (2007, May). The rise of global reporting initiative (GRI) as a case of institutional entrepreneurship. Corporate Social Responsibility Initiative Working Paper No. 36. Cambridge, MA: John F. Kennedy School of Government, Harvard University. Pp. 1-48.

[6] Creel, T. S. (2010). Environmental reporting practices of the largest US companies. Management Accounting Quarterly Fall. 12(1), 13-19.

[7] Dingwerth, K. \& Eichinger, M. (2010, August). Tamed transparency: How information disclosure under the global reporting initiative fails empower global environmental politics, 10(3); 74-96. http://ww.researchgate.net

[8] Enahoro, J. A. (2009). Design and bases of environmental accounting in oil and gas and manufacturing sectors in Nigeria. A PhD Thesis submitted to Department of Accounting, College of Business and Social Sciences, Covenant University, Ota, Nigeria.

[9] Firoz, C. A. M., \& Ansari, A. A. (2010). Environmental accounting and international financial reporting standards (IFRS). International Journal of Business and Management. 5(10); 105-112.

[10] Fortes, H. (2002). The Need for Environmental Reporting by Companies: An Examination of the Use of Environmental Reports by Swedish Public Companies. Greener Management International. Winter 2002. 77-92.

[11] Global Reporting Initiative (2011). GRI and ISA 26000: How to use the GRI guidelines in conjunction with ISO 26000. ISBN: 978-90-8866-041-2. http://www.globalreporting.org

[12] Global Reporting Initiative (2013). G4 Sustainability reporting: Reporting principles and standard disclosures. The Netherlands. http://www.globalreporting.org

[13] Haggins \& Frames (January 2011). Gender mainstreaming toolkit for national environmental policy and processes. A Report submitted to the Ministry of Environment Abuja, Nigeria on Gender and environment.

[14] Hedberg, C. \& von Malmborg, F. (2003). The global reporting initiative and corporate sustainability reporting in Swedish companies. Corporate Social Responsibility and Environmental management, 10; 153-164.

[15] International Trade Centre (2015). Global reporting initiative. Amsterdam, Netherlands. http://www.standardsmap.org 
[16] Jenkins, H. \& Yakovleva, N. (2006). Corporate social responsibility in the mining industry: Exploring trends in social and environmental disclosure, 14; 271-284.

[17] Kantudu, S. A. (2006). Application of accounting standards on employee retirement benefits by quoted firms in Nigeria. PhD Accounting and Finance Thesis. Zaria, Post Graduate School, Ahmadu Bello University.

[18] Kasum, A. S. (2010). Environmental degradation problems caused by human activities in Nigeria: enforced (taxation) versus voluntary (social responsibility) solutions. International Journal of Banking, Accounting, and Finance.2(3); 236-250.

[19] Kornblum, W. \& Julian, J. (1992). Social problems. $7^{\text {th }}$ Edition, United States of America. Prentice Hall Englewood Cliffs, NJ 07632.

[20] Levy, D. L., Brown, H. S. \& de Jong, M. (2010). The contested politics of corporate governance: The case of global reporting initiative, $49(1) ; 88-115$.

[21] Malarvizhi, P. \& Yadav, S. (December 2008/January 2009). Corporate environmental disclosures on the internet: An empirical analysis of social and environmental accounting. 2(2); 211-232.

[22] Milne, M. J., Ball, A., \& Gray, R. (2005). Wither Ecology? The triple bottom line, the global reporting initiative, and the institutionalization of corporate social reporting. Pp. 1-25.

[23] Moneva, J. M., Archel, P., \& Correa, C. (2006). GRI and the camouflage of corporate unsustainability. Accounting Forum, 30; 121-137.

[24] NSE FactBook (2012/2013). Nigerian Stock Exchange.

[25] Nyor, T. (2008). Assessment of the level of accounting information disclosed in the financial statements of Nigerian banks. A Ph.D. Thesis presented to the Department of Economics and Management Sciences, Nigerian Defence Academy, Kaduna.

[26] Othman, R. \& Ameer, R. (2009, March 19 ${ }^{\text {th }}$ ). Corporate social and environmental reporting: where are we heading? A survey of the literature. International Journal of Disclosure and Governance, 6; 298320.

[27] Pramanic, A. K., Shil, N. C. \& Das, B. (March 2008). Environmental accounting and reporting with special reference to India. MPRA (Munich Personal RePEc Archive). http://www.mpra.ub.uni.muenchen.de/7712/ Rahaman, A. S., Lawrence, S. \& Roper, J. (2004). Social and environmental reporting at the VRA: Institutional legacy or legitimation crisis? Critical Perspective on Accounting, 15(1); 35-56.

[28] Rahman, A. A., Hashim, M. F. A. M., \& Abubakar, F. (June 2010). Corporate social reporting: a preliminary study of Bank Islam, Malaysia. Issues in Social and Environmental Accounting, 4(1); 18-39.

[29] Sherman, W. R., (2009, May). The global reporting initiative: What value is added? International Business and Economics Research Journal, 8(5); 9-21.

[30] Tanimoto, K. \& Suzuki, K. (2005, April). Corporate social responsibility in Japan: Analysing the participating companies in global reporting initiative. ResearchGate, 1-20.

[31] Woods, M. (2003, June). The GRI's mission is to promote international harmonization in reporting relevant and credible corporate economic, environmental, and social performance information. The CPA Journal, 73(6); 60-65. 